https://doi.org/10.15407/scin16.06.018

SHYIAN, A.A., AZAROVA, A.A., NIKIFOROVA, L.O.,

TKACHUK, L.M., and AZAROVA, V.V.

Vinnytsia National Technical University,

95, Khmelnytske Schose St., Vinnytsia, 21021, Ukraine,

+380 43256 0848, vntu@vntu.edu.ua

\title{
MODELING COMMUNICATION BETWEEN THE PUBLIC AND THE AUTHORITIES WHILE IMPLEMENTING INNOVATIVE PROJECTS IN THE CONTEXT OF E-DEMOCRACY AND PUBLIC ADMINISTRATION
}

Introduction. E-democracy and e-government become an increasingly common attribute of people's lives, since they give is an opportunity to attract population masses to the discussion of both economic and social, as well as managerial innovations. The society urgently requires innovation in the organization of public and regional administration.

Problem Statement. Adjemoglu and Robinson have shown that the necessary factor for the success of public or region development is the presence of inclusive political and economic institutions. Inclusive institutions involve the widest possible population in decision-making. Moreover, namely the political institutions (which are crucial for involving as much as possible the public to making decision) determine successful development of society.

Innovative projects are the driver of economic development, so the involvement of the general public in their discussion, decision-making, implementation and analysis of the results is an extremely important factor. Many authors have emphasized that the digitalization of information is an important factor for the formation and development of a developed society.

Purpose. The purpose of this research is to develop approaches to modeling the communication channels of the public and authorities under the conditions of innovation project implementing in the context of e-democracy and public administration.

Materials and Methods. The research uses the methods of system analysis, game theory, structural, functional, and logical analysis.

Results. Innovative projects are supported primarily by the middle class, as evidenced by the Hotelling model (the median voter model). The analysis of existing in Ukraine functional model of communication between the public and the authorities while implementing innovation projects has revealed a number of its shortcomings. To correct them, a scheme for optimizing the communication between the authorities and the public by means of e-democracy while implementing an innovation project has been proposed. The necessity of attracting media, experts, and analysts at each stage of the implementation of the innovation project has been justified.

Цитування: Shyian A.A., Azarova A.A., Nikiforova L.O., Tkachuk L.M., and Azarova V.V. Modeling Communication Between the Public and the Authorities while Implementing Innovative Projects in the Context of E-Democracy and Public Administration. Nauka innov. 2020. V. 16, no. 6. P. 18-27. https://doi. org $/ 10.15407 / \operatorname{scin} 16.06 .018$ 
Conclusions. The described communication channel includes electronic media and the community of experts and analysts as compulsory components. It enables the creation an effective system of feedbacks between the authorities and the public which allows making optimal decisions and monitoring the socio-economic development of society.

Keywords: modeling, interaction, power, public, public administration, electronic media, expert, and analyst.

The feedback from the public to the government institutions of the state, region or community is a decisive factor in ensuring the effectiveness of these institutions' activities. The absence or even the difficulty or delay in the transmission of information from the public to the institutions of governance and from the institutes of governance to society necessarily leads to negative consequences. In particular, very because of this, citizens are forced to go on strike because they only such way they can pass on their opinion to the leadership of the state or region.

During the innovative projects implementation e-democracy tools provide a large number of new channels for feedback from the public to the authorities. They also allow the justification of decisions from the authorities to the public. This new factor for Ukraine requires significant communication between the authorities and the public.

Thus, the study of the peculiarities of communication between the public and government in the process of innovative projects implementation under the conditions of electronic democracy is an actual scientific and important practical problem.

Analysis of recent research and publications. As it has been shown in $[1,2]$ the necessary factor for the success of the public or region development, especially in the context of innovative projects implementation, is the presence of inclusive political and economic institutions.

Inclusive institutions [2] involve population masses in decision-making. Electronic democracy (e-democracy) is a powerful tool for the effective functioning of such institutions.

In the strategy for the development of the information society in Ukraine [3], e-democracy is defined as "a form of social relations in which citizens and organizations are involved in statebuilding and public administration, as well as in local self-government through the wide use of information and communication technologies".

It is emphasized in $[4,5]$, that in the general sense e-democracy implies involving the public in solving various socio-political tasks with the help of modern information technologies.

Today, Ukraine is in a state of hybrid war, when the informational and psychological influence from the outside sometimes affects the lives of citizens both at the state level and at the regional level [6]. As a result, electronic media become almost the only source of information for the population. Today, all mass media actively operate in electronic form, therefore, in our research the term "mass media" will be applied to their electronic form. Social networks are not yet controllable; besides, in emergency situations they usually carry out destructive influence, causing panic, violence and fatalism. So it does not help in emergency resolution. The psychological reasons of this are described in [7], and consolidated effects (mostly destructive) are called in [8] "crowd effects".

R. Bauer [9] in her blog analyses lections of Michael Woolcock, Lead Social Development Specialist at the World Bank and lecturer in public policy at the Harvard Kennedy School, discusses critical ideas within the field of Social Development. She emphasizes that the lecturer focuses on the fact that social development requires strong institutions that are aimed at strengthening the individual ability of people to function and perform tasks in a modern changing world. R. Bauer emphasizes [9], "This is why Michael Woolcock emphasizes that development could be more effective if it focused on building the capability of systems, not just the capacity of individuals". 
In the other blog R. Bauer says [10], "There are parallel and equally unsettling trends occurring worldwide: trust in media is falling as people are increasingly unable to discern credible information while trust in national governments worldwide (although with more pronounced distrust in developed countries) is also deteriorating." Author emphasizes, "Governments are now struggling to keep pace with how modern voters gather information and form their opinions. Since governments rely on the consent and trust of the people for their legitimacy and authority, falling levels of trust in government is a key issue facing government communicators." So, there is an important problem of communication between government and society. For Ukraine whose economy requires innovative development this problem is exacerbated many times.

W. Eggers's book [11] is an example of a rapidly expanding literature that explores the evergrowing changes that the digital world is bringing to society. He draws close attention to the fact that electronic communication means require a fundamental change in state and regional governance. It also requires the involvement of an increasing number of people in decision-making processes at the state and region level. The author states, "Delivering on digital explores how a new generation of digital innovators are using tools such as cloud computing, mobile devices, and analytics to reform and modernize long-standing processes within government. It showcases dozens of case studies of governments from Estonia to San Francisco that have successfully increased citizen engagement and expanded their capabilities and efficiencies with digital technologies. We now have the digital tools and the talent to stage a real transformation in government. A digital mindset is a different way of thinking about customers, products, and process. It is faster, iterative, and adaptable. And if government adopts it, the changes can be revolutionary."

The book [11] pays attention to the fact that government officials around the world are working on similar systems for people to receive vari- ous benefits, for example, subsidies or vocational training in employment centers. These new case management systems are trying to identify real needs, not just eligibility for benefits. They exempt employees from multi-page paper applications for each individual program. Integrated systems of state and regional management are based on information and web technologies. They can greatly simplify the process for residents to apply for a new program or restore its right to an existing one. An applicant who gains access to information via the Internet can transforms a state or regional government process to a single process. New digital systems allow governments to more accurately track whether government programs are working and to better understand how these programs can be improved. However, the problem of trust between the government and society again arises.

C. Charbit and O. Romano [12] pay attention to the implementation of contracts between the administration and the public. The authors distinguish three types of contracts: i) empowerment; ii) delegation; and iii) policy-sharing contracts. The authors note, "Evaluation should be carried out in a consistent time-frame, taking into account that regional development policies generate impacts over a long period of time. Enforcement pushes the parties to comply with their agreements, through internal and external mechanisms. Stakeholder expectations are a driver to make policy-makers more accountable and their behaviour more transparent. But in order to do so, it is important to set the conditions for the stakeholders to operate their "control", through availability of information, consultation and other forms of engagement. Informal enforcement mechanisms may be requested and applied in those national cultures more oriented towards trust and mutual responsibility. The choice of the appropriate enforcement and evaluation processes, depending on the various objectives for which countries use contracts across levels of government, is crucial and merits further exploration." In conclusion, the authors propose coercive mechanisms for more efficient execution of contracts between adminis- 
trations of all levels and by the population. Thus, the involvement of the population at all stages of the consideration, adoption and implementation of contracts, especially innovative contracts, is an important stage in the development of modern society and management mechanisms.

In review OECD (2017) [13] "Fostering Innovation in the Public Sector" the main attention is paid to the requirements for state and regional government bodies that will contribute to the innovative development of the state and society. In particular, "Today, governments are starting to look at transforming systems to put individual and social outcomes at the heart of policy approaches. To achieve this, governments must not only be innovative; they must also create the right conditions for innovation within and across systems. This means being able to identify problems and translate ideas into projects that can be piloted on a small scale and then implemented and diffused to effect system-wide change. It also means recognising the processes and structures that can support and accelerate innovation." The review emphasizes the need to create structures and mechanisms that maximally involve all sectors of society for discussion, decision-making, implementation and the subsequent result of innovation. At the same time attention is drawn to the urgent need to create the conditions for this.

Thus, the study of the peculiarities of communicating the public with the authorities at different levels during the implementation of innovative projects in the conditions of electronic democracy is an actual scientific problem and important in the practical realization of the task.

The purpose of the article is to develop approaches to modeling the communication channels of the public and authorities under the conditions of innovation project implementing in the context of e-democracy and public administration.

\section{THE MODELING OF MAKING DECISION BY THE PUBLIC}

Consider the construction of a mathematical model for describing the peculiarities of making de- cision by the public in the process of it communicating with the state and regional authorities. To do this, we modify the well-known model of Hoteling [9], which allows aggregating of the individual preferences.

Let's describe the classical Hoteling's model on the basis of $[1,14,15]$ with modifying it for the conditions of our task.

Let's consider the individual preferences of people for their use when they make a common choice by voting. To do this, we will use the wellknown "utility function" $[15,16]$, which allows analyzing of the various alternatives. The utility feature helps a person to organize his thoughts, choose the best of all solutions, comparing them with each other. In other words, the utility function can reveal the benefits of one solution compared to others.

Let's consider the case when the utility function of an individual is convex upward and has one maximum (has one peak). This means that our individual chooses the only one opinion (decision) that is most appropriate for him from all possible choices. Every other decision (opinion), information and alternative the individual considers "less important" for himself. And the "further" this thought, this alternative lies on the "peak", so it is less important for him or the less he trusts her.

Example 1. Consider one-dimensional set of possible individual thoughts regarding the causes of any political, economic or emergency situation. This could be, for example, a set of opinions such as "terrorists carrying out a terrorist act" due to "lack of state control" to the point of view "this happened on its own". There are individuals who are sincerely confident in the "conspiracy theory", while others are absolutely certain that "bad ecology is to blame". The more distant the opinion of the media, the less trusting in it is a person who holds a different opinion.

Mathematically, the "one-step" function of the individual's preferences can be defined in next way. We denote $q$ as the preference of this individual and $Q$ as the set of possible preferences of 

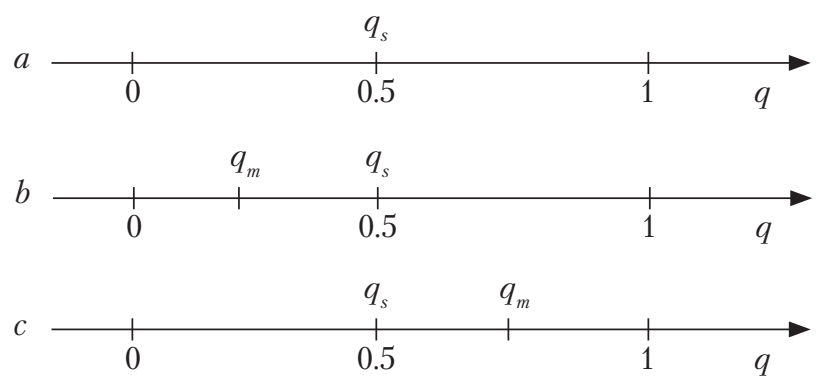

Fig. 1. The ratio between the average value of the possible choice and that of the choice of the median individual

all people. We consider this set to be "ordered", that is, there are operations "<" ("greater"), "=" ("equal" or "equivalent") and ">" ("less") on the $Q$ set. This means that the individual is able to compare the thoughts (results of the decisions taken, the results of the choice made, etc.) among themselves. Denote by $V^{\prime}(q)$ - the indirect utility function for the $i$-voter. This function allows the individual to determine which preference is most appropriate to him. In general, for each of $N$ individuals there is a function of utility.

Each individual, for example a voter $i$, has its own "perfect point" which is the value of a characteristic $q_{i}$, that gives the maximum value to its indirect utility function $V_{i}\left(q_{i}\right)$. In other words, it is a point for the $i$-voter that for any value of another preference $q$ there is a ratio $V^{\prime}\left(q_{i}\right) \geq V^{\prime}(q)$ for all $q \in Q$.

This is the definition for the "one-step" function of the utility of the individual ("voter"), which is also called the "one-peak" function of preferences when individuals make their social choice.

Let's introduce the concept of "median" individual. The median individual is called an individual $M$, for which the number of individuals with individual preferences satisfying the relationship $q_{i}<q_{m}$ is the same as the number of voters whose individual preferences satisfy the relationship $q_{i}>q_{m}$. In other words, the "median" individual divides all people into "two half". The first half consists of individuals whose preferences are less important for the median voter, and the other vice versa.
The wide application of the above-described approach to the description of social choice is based on the median voter's theorem (MVT) [14]. The formulation of the theorem is given in $[1$, p. 94] and a translation into Ukrainian [15, p. 64].

The median voter's theorem of Hoteling. Consider a set of possible choices for an individual $Q \subset R$, let $q \in Q$ is the individual choice, and let $M$ is the median individual who chooses the ideal point $q_{m}$. If all individuals have the one-peak functions of $Q$, then:

1) $q_{m}$ always wins any other alternative $q^{\prime} \in Q$ if $q^{\prime} \neq q_{m}$ at pair competition;

2) $q_{m}$ is always the winner in a direct voting with an open list.

The modeling of communication between the public and authorities during the innovative projects implementing. Apply MVT to modeling of communication between the public and authorities during the innovative projects implementing in the context of e-democracy and public administration.

Public opinion, that is, the aggregated set of human preferences, is formed now by the media. Caused by development of e-democracy, the intensity of this process will only grow. Using MVT proves that the main contribution to public opinion is made by the median individual. Therefore, the formation of the median individual "necessary" thought is an important component of the interaction of management structures and mass media both at the national and regional levels.

It should be emphasized that the choice of median individual $q_{m}$ does not match, as a rule, with the mean $q_{\mathrm{s}}$ of a possible choice for all individuals. Consider possible situations on fig. 1.

In Fig. 1, $a$ the value $q_{\mathrm{s}}$ of the possible choice's average is equal to the value $q_{m}$ of the choice of median individual. This situation occurs as a rule in cases where the preferences of people are evenly distributed over the whole range of possible preferences.

Fig. 1, $b$ shows the case when the preferences of the median individual $q_{m}$ are smaller and shifted to the left than the possible choice's average $q_{\mathrm{s}}$. 
It means that most individuals choose less value of the preferences than the average. Fig. $1, b$ shows an inverse case.

Methods of using the model for communication of society and government. During communication between state and regional authorities and the public it is important to create such a public opinion that will help society in its effective development, primarily by implementing innovative projects and will eliminate the unwanted deviations (for example, the negative consequences of emergencies). The most powerful channel for this is the media.

It should be noted that the electronic communication channel between the public and government provides a unique (now there is only one) opportunity for Ukraine to justify those decisions which are making by state and regional authorities. Moreover, only the electronic communication channel is capable to provide an effective feedback from the public to the authorities at the stages of discussing proposals and analyzing of the consequences of proposed government making decisions. From this position, such a method of using electronic mass media becomes the most important factor of e-democracy in Ukraine.

The Hoteling's theorem MVT is, in essence, the main model that describes the mechanism of making decision by society. It has led to the emergence of a concept of "middle class". To be able to reliably forecast the public making decisions we need information on the preferences of those individuals who are located near the "medical voter". And the more preferences of this society do not differ much from the median voter's preferences, the more reliable will be the prediction of the public decision making.

Another limitation of using the Hoteling's theorem is that individuals must consciously make their choices. That is, they should have full and objective information about the consequences that follow from it.

Thus, forecasting the future development of the society requires, in essence, the existence of two conditions:

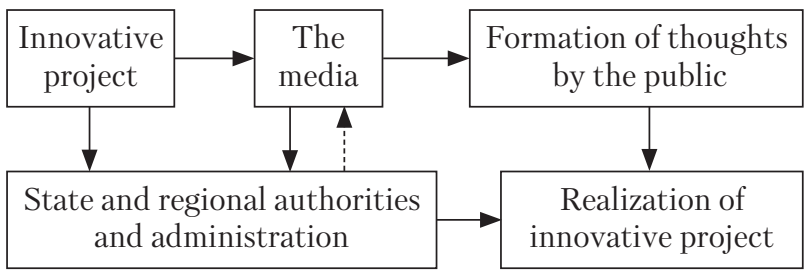

Fig. 2. Existing functional model of the public and authorities communication during implementation of innovation project

1) the presence of a large number of people belonging to the "middle class", the choice of which does not differ from the choice of the median voter;

2) all "middle class" voters should have full and objective information about the consequences of the their decision.

E-democracy and e-government $[4,5]$ should focus precisely on the implementation of these two conditions. In particular, the condition of increasing the "middle class" belongs mainly to economic conditions. However, economic conditions (more precisely, economic institutions) are the result of the public choices. In this very sense we have should understand D. Adjemoglu and J. Robinson's thesis that the political institutions (which are crucial for involving as much as possible the public to making decision) determine successful development of society [2].

Today in Ukraine the channel for electronic communication between the community and the government is ineffective. The functional model of the activity of this channel today during the implementation of the innovation project is shown in Fig. 2.

Today in Ukraine the channel for electronic communication between the public and the authorities is ineffective. The functional model of the activity of this channel today during the implementation of the innovation project is shown in Fig. 2.

State and regional authorities propose to the public a certain innovation project (for example, for local budget expenditures). Electronic media inform the public about this project. Unfortunately, such process is realized practically without analytical support. In addition, often the employees 


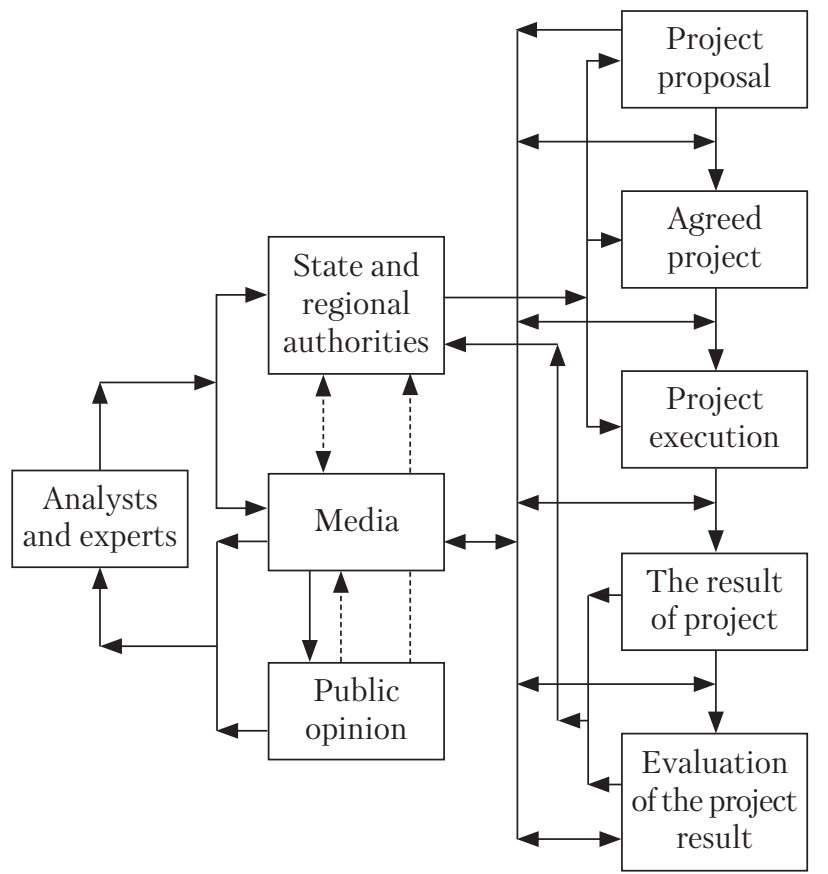

Fig. 3. The scheme for optimizing the communication of authorities and the public by means of e-democracy during the implementation of the innovation project

of state and regional authorities become the "experts" although they are not impartial. In addition, electronic media often observe only the interests of their owners. All this leads to the fact that information that comes to the public is usually incomplete and distorted (biased). And even the presence in Ukraine of quite a large number of different electronic media does not help citizens to obtain objective information, because for this he would have to carry out a serious analytical study which demanding from the citizen considerable professional skills and great resources of time.

In essence, the state and regional authorities appear in the media only "as necessary", like a result of a request from the media it is shown by dotted lines in Fig. 2. As a rule, they are not interested in the opinion of the public. In particular, so-called "public discussions" are carried out only formally: reactions and arguments from the authorities to such discussions are usually not announced.

Let's describe the model of channel operation for optimal communication between the authori- ties and the public during implementing an innovation project, which meets the requirements of e-democracy [4, 5]. According to [3-5], the main subjects of communication are the power and the public, and the main actors are the media (which today are virtually all electronic) and public opinion (which reflects the information processes in the society). Today in Ukraine there is not yet another very important participant of the information process - experts and analysts.

Activities of state and regional authorities are carried on the basis of implementation of individual projects, which are limited by the given time. Electronic democracy requires the public to be involved in this activity at all stages of project development and implementation. Schematically, the implementation of this is depicted in Fig. 3.

An important role in communicating power and community is played by electronic media. They are the ones who inform the authorities about the needs of the public. The role of experts and analysts in Ukraine is significantly underestimated and it is ignored too often. Besides, unfortunately, in Ukraine lots of "analysts and experts" are unable to complete their tasks.

In fact, a new innovative project begins from the analysis of the public opinion by analytical structures it allows allocating a certain task as an urgent one. This task is the one which is most important for the public in the current moment.

This is, in fact, the first stage of communication.

At the second stage, mass media are launching public discussion of the problem.

At the third stage the government is involved in communication, starting to develop an innovation project as a response to expressed, with help of media, needs of the public. The proposition of innovation project (in fact, version for further public discussion) is presented to inform the general public.

The fourth stage is a broad discussion of the version of innovation, which is consistent with the government (that is, the government proposes such problem's solution that the public is satisfied). This discussion is carried out not only 
through the media, but also in social networks, and so on. Analysts and experts are involved in all channels of communication both with the authorities and with the public. It should be noted that the task of analysts also includes the interpretation for various layers of the public agreed with the authorities of the innovation project. Besides, the government structures are not able themselves, without the help of independent analysts and experts, to organize effectively such communication with different layers of the public.

In such discussion analysts and experts are an interface between the authorities and the public. The result of their work is the amendment and clarification of an innovation project agreed with the authorities.

At the fifth stage, the government adopts the coordinated innovation project and submits it for information to the public. It is very this project will be executed.

The sixth stage is the actual implementation of the innovation project. This stage is widely described with the media and is controlled by the authorities. It is also thoroughly analyzed by independent experts and analysts who with help of media report their conclusions to the public. This allows the authorities in-time make the necessary corrections during the project implementation. Experts and analysts also have to take into account the response of the public opinion to the implementation of the innovation project.

The seventh stage is the implementation of an innovation project. Here, the authorities as widely as possible through the media inform the public about the results.

However, the very results of the project are already being analyzed at the eighth stage because the results of almost every innovation project are distributed in time. Besides, if at the beginning of the innovation project and during its implementation, the main focus of public attention is focused on what will be achieved and achieved as a result of implementation, then after implementation it becomes important to take into account the loosing opportunities resulting from the imp- lementation of this particular project. In other words, the public begins to pay attention to other innovative projects that could be implemented instead.

The role of independent experts and analysts at this stage is important. In fact, immediately after the innovation project presentation, experts and analysts and media should co-work both in the direction of "mass media experts and analysts", as well as in the direction of "experts and analysts $\rightarrow$ mass media". To realize this, it necessary to use materials specifically prepared by analysts and experts. It is also very important at the stage of project implementation to quickly bring to television, radio, electronic media experts and analysts who use pre-prepared workpieces. In particular, they should interest the media, for example, with high-quality infographics.

Fig. 3 shows with dashed lines the interaction between subjects which is carried out indirectly and implicitly. For example, public opinion influences the activity of the media implicitly, creating ethical and aesthetic norms and rules of journalist's behavior or the rules of communication and conditions of working in social networks. Mass media implicitly affect to employees of state and regional authorities, informing them about the needs of the population and its reaction to the actions of the administrative structures. Public opinion also affects to the power, for example, through communicating with friends, comrades and relatives.

Example 2. Another interesting fact is that during the interaction between the authorities and the public other sources of influence on public opinion can also be widely used. For example, movies are very effective. In particular, information about possible natural or technological catastrophes, their prevention and liquidation of consequences is widely used in Japan, South Korea, the United States and several other countries in the form of movie-actions, movie-disasters, etc. Also, effectively use the literature of the relevant genres.

Thus, the application of the proposed channel model for optimal communication between the 
authorities and the public during the implementation of innovative projects enables not only effective transfer of information for analysis and substantiation from the government to the public, but also the public effectively influence on the decisions taken by the power. A main factor here is a set of experts and analysts, as well as their relationship with the community, communication channels (like the electronic media) and authorities.

As a result of such a model, the median voter (i.e. the social group in which the median voter is located) gets all the information he needs to make the best choice. The set of feedbacks between the public and the authorities enables effective management of society socio-economic development.
The problem of communicating the public and government during implementing the innovation project in the context of e-democracy and public administration is proposed. The model of making a common solution for aggregating the preferences of individuals is adapted to the conditions of the task. It allows proposing the functional model for interaction between state and regional authorities and the public. The described communication channel includes electronic media and the community of experts and analysts as compulsory components. It enables creation an effective system of feedbacks between the authorities and the public which makes it possible to make optimal decisions and to control the socio-economic development of society.

\section{REFERENCES}

1. Acemoglu, D., Robinson, J. A. (2006). Economic origins of dictatorship and democracy. Cambridge University Press.

2. Acemoglu, D., Robinson., J. A. (2012). Why Nations Fail: The Origins of Power, Prosperity, and Poverty. Crown Publishers.

3. On Approval of the Strategy of the Information Society Development in Ukraine: Order of the Cabinet of Ministers of Ukraine of May 15, 2013. № 386-r. Official Bulletin of Ukraine. No. 44. Art. 1581 [in Ukrainian].

4. Grycyak, N. V., Soloviev, S. G. (2015). Electronic democracy. Kyiv: NADU [in Ukrainian].

5. Malinovsky, V. Ya., Gritsiak, N. V., Semenchenko, A. I. (2017). Conceptual Principles of Electronic Governance and Electronic Democracy. Kyiv: FOP Moskalenko O.M. [in Ukrainian].

6. Felshtinsky, Yu., Stanchev, M. (2015). Third World: The Battle for Ukraine. Kyiv: Nash format [in Ukrainian].

7. Varii, M. Y. (2009). Psychology. Kyiv: Tsentr Uchbovoi Literatury [in Ukrainian].

8. Le Bon, Gustave. (1905). Psychologiedes Foules. F lix Alcan.

9. Bauer, R. (2017a). Building capacity vs. building capacity: Why development needs 'System thinking. World Bank. URL: http://blogs.worldbank.org/publicsphere/building-capacity-vsbuilding-capacity-why-development-needs-systemthinking (Last accessed: 16.12.2019).

10. Bauer, R. (2017b). Democracy only works if we show up. World Bank. URL: https://www.worldbank.org/en/webarchives/archive?url=http\%3A\%2F\%2Fweb.worldbank.org\%2Farchive\%2Fwebsite01603\%2FWEB\%2FDEMOCRAC. HTM\&mdk=435714967 (Last accessed: 16.12.2019).

11. Eggers, W. (2016). Delivering on Digital: The Innovators and Technologies that are Transforming Government. Deloitte University Press.

12. Charbit, C., Romano, O. (2017). Governing together: An international review on contracts across levels of government for regional development. OECD Regional Development Working Papers, No/ 2017/04, OECD Publishing, Paris.

13. OECD (2017). Fostering Innovation in the Public Sector. Paris, OECD Publishing. URL: https://doi.org/10.1787/ 9789264270879-en (Last accessed: 16.12.2019)..

14. Hoteling, H. (1929). Stability and competition. Econiomic Journal, 39(153), 41-57.

15. Shiyan, A. A. (2010). Management of the development of socio-economic systems. Theory of Games: Fundamentals and Applications in Economics and Management. Vinnitsa: VNTU [in Ukrainian].

16. Neumann von, J., Morgenstern, O. (1944). Theory of Games and Economic Behavior. Princeton University Press.

Стаття надійшла до редакціi / Received 10.04.19

Статтю прорецензовано / Revised 11.11.19

Статтю підписано до друку / Accepted 15.01.20 
Шиян А.А., Азарова А.О., Нікіфорова Л.О., Ткачук Л.М., Азарова В.В.

Вінницький національний технічний університет,

Хмельницьке шосе, 95, Вінниця, 21021, Україна,

+380 432560848 , vntu@vntu.edu.ua

\section{МОДЕЛЮВАННЯ КОМУНІКАЦІЇ МІЖ ГРОМАДСЬКІСТЮ ТА ВЛАДОЮ ПІД ЧАС ВПРОВАДЖЕННЯ ІННОВАЦІЙНИХ ПРОЄКТІВ У КОНТЕКСТІ Е-ДЕМОКРАТІЇ ТА ДЕРЖАВНОГО УПРАВЛІННЯ}

Вступ. Електронна демократія та е-уряд стають все більш поширеними в житті суспільства - дають можливість залучити широкі маси населення до обговорення економічних, соціальних, управлінських рішень, що вимагає невідкладних інновацій в організації державного та регіонального управління.

Проблематика. Необхідним фактором для успішного розвитку суспільства чи регіону є наявність інклюзивних політичних та економічних інституцій. Перші залучають якомога ширше населення до участі у прийнятті рішень, визначають успішний розвиток суспільства. Інноваційні проєкти є рушієм економічного розвитку, тому залучення громадськості до їх обговорення, затвердження, впровадження та аналізу результатів є надзвичайно важливим фактором. Низка дослідників підкреслюють, що оцифрування інформації є важливим для формування та розвитку сучасного суспільства.

Мета. Розроблення підходів до моделювання каналів комунікації громадськості та влади в умовах реалізації інноваційних проєктів у контексті е-демократії та державного управління.

Матеріали та методи. Використано методи системного аналізу, теорії ігор, структурного, функціонального та логічного аналізу.

Результати. Інноваційні проєкти підтримуються переважно середнім класом, про що свідчить модель Хотелінга (модель медіанного виборця). Аналіз наявної в Україні функціональної моделі комунікації громадськості та влади під час впровадження інноваційного проєкту виявив низку їі недоліків, для усунення яких запропоновано схему оптимізації спілкування влади та громадськості шляхом електронної демократії під час реалізації інноваційного проєкту. Обгрунтовано необхідність залучення ЗМІ, експертів та аналітиків на кожен етап його реалізації.

Висновки. Розроблений канал зв'язку охоплює електронні ЗМІ та спільноту експертів і аналітиків як обов'язкову компоненту. Це дозволяє створити ефективну систему зворотнього зв'язку між владою та громадськістю для прийняття оптимальних рішень та контролю соціально-економічного розвитку суспільства.

Ключові слова: моделювання, взаємодія, влада, громадськість, державне управління, електронні ЗМІ, експерт, аналітик. 